\title{
DESCRIPTIONS OF TWO NEW SPECIES OF PULTENAA.
}

By R. T. Baker, F.L.S., Assistant Curator Technological Museum, Sydney.

(Plate xvi.)

Pultenæa Deanei, sp. nov.

An erect, divaricate villous shrub, with terete branches almost hidden by the numerous leaves. Leaves on short petioles of about 1 line long, obovate, cuneate, obtuse, 4 to 6 lines long, margins slightly incurved, trinerved and reticulate on the underside, midrib not very distinct on the upper surface, hairy on both sides. Stipules prominent, nearly 3 lines long, subulate. Flowers terminal, with small floral leaves on the calyx. Bracteoles inserted on the calyx, acuminate. Calyx villous, 4 lines long or more, lobes rather longer than the tube, the upper ones broad, acute, united to the middle. Standard 6 lines long, the lower petals shorter, keel almost truncate; all the petals light yellow. Ovary glabrous, with a tuft of white, rigid hairs at the summit. Pod unknown.

Hab.-Peat's Ferry, Hawkesbury River (H. Deane) : Thornleigh Cowan Creek (R. T. Baker).

This plant has long been known to Mr. H. Deane, M.A., F.L S., who has always insisted upon its specific rank in opposition to other botanists who have placed it with $P$. elliptica in their herbaria, although its affinities with that species are not at all well marked.

Its general aspect is perhaps somewhat similar to $P$. elliptica, but a detailed examination of its parts reveals many affinities with $P$. largiflorens, so that in botanical sequence $I$ think it should come between that species and P. villosa.

It resembles $P$. largiflorens, F.v.M., in the shape both of its leaves and calyx, but differs from it in indumentum, length of 
stipules, its larger leaves, and petals, and larger terminal, entirely yellow flowers, and glabrous ovary.

Its affinities with $P$. villosa, Willd, are not very marked, except in indumentum and some resemblance in the shape of leaves. It is, however, a much more divaricate, rigid plant than that species.

Except from its generic characters it is hard to state where its alliance with $P$. elliptica comes in, as it differs from it (1) in its sessile floral leaves ; $(2)$ the bracteoles inserted on the calyx ; $(3)$ indumentum; (4) vestiture of calyx; (5) the shape of the lobes of the calyx; (6) length of calyx; (7) acuminate stipules; (8) petals all yellow.

\section{Pultenea acuminata, sp.nov.}

An erect, or prostrate, virgate, low shrub, flowering when only a few inches high. Leaves irregularly opposite or in whorls of 3 or 4, or even decussate, softly pubescent when young, acuminate, rounded or cordate at the base, under 6 lines long, rigid, convex, the midrib as well as the veins prominent on both sides, scabrous above, long silky hairs on the underside, petiole about 1 line long. Stipules minute and very deciduous. Flowers pedi. cellate, in dense, terminal heads, much exceeding the last leaves. Bracts lanceolate with a long acuminate, subulate point, ciliate with long silky hairs, reticulations prominent on the underside, 2 to 4 lines long. Bracteoles close under the calyx, pubescent, linear, subulate, about half the length of the calyx. Calyx hairy, about 4 lines long, tube short, the two upper lobes united to the middle, acuminate, the lower ones not quite so long, but with acuminate points similar to the upper ones. Petals about as long as or a little longer than the calyx, nearly all of equal length; standard broad, dark coloured in the centre; the keel very dark, hood-shaped, obtusely lobed, the wings a shade lighter in colour. Ovary sessile, covered with long silky hairs and tapering into a subulate style.

Hab.-Ranges on the right bank of Bylong Creek, N.S.W. (R.T.B.) 
As the leaves of this species are mostly in whorls or decussate, it is allied to the species placed by Bentham under Section III. Euchilus, of this genus. In this division the species are classified according to the convexity, concavity, or flatness of the leaves, and this species having convex leaves with recurved margins similar to those of $P$. cordata and $P$. rotundifolia, I think in botanical sequence it should be placed after $P$. aspalathoides, and thus it would form a connecting link between the Sections Aciphyllum and Euchilus, (B. Fl. II. p. 109), as it resembles the $P$. aspalathoides of the former section in its terminal heads of flowers, and also somewhat in the size and shape of its leaves.

It differs, however, from that species in having convex, opposite leaves and not concave alternate leaves, and the standard is also smaller.

Its most characteristic difference from $P$. obcordata and other species of this group is the shape and size of the leaves, but other. wise it resembles them in its opposite whorled leaves.

\section{EXPLANATION OF PLATE.}

\section{Pultencea Deanei.}

Fig. 1.--Flowering twig.

Fig. 2.-Bud (enlarged).

Fig. 3.-Calyx ,,

Fig. 4.-Standard,,

Fig. 5.-Keel ,,

Fig. 6.-Wing ,, 


\section{$2 \mathrm{BHL}$ Biodiversity Heritage Library}

Baker, Richard T. 1898. "Descriptions of two new species of Pultenaea." Proceedings of the Linnean Society of New South Wales 22, 438-440.

https://doi.org/10.5962/bhl.part.12728.

View This Item Online: https://www.biodiversitylibrary.org/item/22896

DOI: https://doi.org/10.5962/bhl.part.12728

Permalink: https://www.biodiversitylibrary.org/partpdf/12728

\section{Holding Institution}

MBLWHOI Library

Sponsored by

MBLWHOI Library

\section{Copyright \& Reuse}

Copyright Status: NOT_IN_COPYRIGHT

This document was created from content at the Biodiversity Heritage Library, the world's largest open access digital library for biodiversity literature and archives. Visit BHL at https://www.biodiversitylibrary.org. 